\title{
Communication
}

[Comunicação]

\section{Action time and feed frequency of Lactobacillus plantarum for Nile tilapia}

[Tempo de ação e frequência alimentar do Lactobacillus plantarum para tilápia-do-nilo]

\section{A. Jatobá ${ }^{1,2}$, M. O. Pereira ${ }^{1}$, L. M. Vieira ${ }^{1}$, M. Bitencourt ${ }^{1}$, E. Rodrigues ${ }^{1}$, F. A. Fachini ${ }^{1}$, A. V. Moraes ${ }^{1}$}

${ }^{1}$ Laboratório de Aquicultura, Instituto Federal Catarinense - Araquari, SC

${ }^{2}$ Programa de Pós-Graduação em Produção e Sanidade Animal, IFC

Probiotics may be defined as live microorganisms that colonize the digestive tract of aquaculture animals in order to improve their health (Gatesoupe, 1999), among the microorganisms with probiotic potential, the use of lactic acid bacteria (LAB) is highlighted based on their ability to inhibit the growth of pathogenic bacteria by the production of antimicrobial compounds, such as bacteriocins, hydrogen peroxide acid, lactic acid and reuterin (Balcázar et al., 2008; Newaj-fyzul et al., 2014). In the aquaculture industry, they are mainly used as a prophylactic measure (Ringø et al., 2014).

The LAB has shown beneficial effects in main aquatic organisms reared in Brazil, such as Nile tilapia juveniles (Jatobá et al., 2008, 2011; Van Hai, 2015) and fingerlings (Jatobá e Mourinõ, 2015) and white Pacific shrimp (Vieira et al., 2008; Jatobá et al., 2011). In all of these researches, probiotics have been constantly offered for fish and/or shrimp, and they have reported positive changes in host microbiota and immune system, although there are few studies that aim to optimize the probiotic use. Thus, the aim of this research was to evaluate the action time of LAB (Lactobacillus plantarum) in the intestinal tract, as well as, in what frequency the LAB should be offered, for Nile tilapia (Oreochomis niloticus).

\section{METHODOLOGY}

The study was carried out in the Laboratório de Aquicultura (LAQ), Instituto Federal Catarinense (IFC), campus Araquari, (Protocol number
0156/2016 approved by by animal ethics committee) and divided into two steps.

The experimental diet was sprayed with the selected LAB previously grown in MRS at a concentration of $1 \times 10^{11} \mathrm{CFU} \mathrm{mL}^{-1}$ and rate of $100 \mathrm{~mL} \mathrm{kg-1}$ feed. The sprayed feed was incubated for $24 \mathrm{~h}$ at $35^{\circ} \mathrm{C}$ in a hermetically sealed container. Next, the feed was dried in an oven for $24 \mathrm{~h}$ at $35^{\circ} \mathrm{C}$. The control feed was sprayed with a sterile MRS culture medium. To quantify $\mathrm{LAB}$ content in the feed, five serial dilutions $(1: 10)$ were carried out. The $10^{3}, 10^{4}$, and $10^{5}$ dilutions were grown in a MRS. The final LAB count in the supplemented feed was $1 \times 10^{7}$ colony forming units (CFU) $\mathrm{g}^{-1}$ feed (Jatobá et al., 2008).

The LAB strain (L. plantarum) used in this research, it was isolated from the intestinal tract of healthy Nile tilapia, and was submitted and approved by in vitro tests (inhibition on disc) and in vivo with fingerlings (Jatobá and Mouriño, 2015).

On the first step, 48 Nile tilapia (O. niloticus) fingerlings were used, with an average weight of $17.3 \pm 3.4 \mathrm{~g}$ and average length of $9.8 \pm 0.7 \mathrm{~cm}$, from the Laboratório de Aquicultura (IFC, campus Araquari)

Nile tilapia fingerlings were transferred to six polyethylene boxes (22L), eight fish in each box experimental unit, equipped with a recirculation system, canister filter and thermostats to keep constant temperature $\left(26-28^{\circ} \mathrm{C}\right)$. The dissolved

Recebido em 21 de março de 2017

Aceito em 19 de junho de 2017

E-mail: jatobaadolfo@gmail.com 
oxygen maintained above $4.0 \mathrm{mg} \mathrm{L}^{-1}$, and $\mathrm{pH}$ measured at the beginning $(6.9 \pm 0.0)$ and final (7.0 \pm 0.1$)$ of the experiment.

The six experimental units were divided into two treatments, fish fed a diet supplemented with Lactobacillus plantarum (probiotic) and fish fed a diet supplemented with sterile culture medium (control).

The fish were fed twice daily with commercial diet (GUABI@ $55.0 \%$ crude protein, $10.0 \%$ moisture, $8.0 \%$ lipid, $3.0 \%$ crude fiber, $1.2 \%$ ash, $14 \mathrm{mg}$ phosphorus $1.5 \%$, calcium $3.0 \%$, size $1 \mathrm{~mm}$, extruded, manufacturer guarantee levels), for 14 consecutive days, according to the previously established treatments, after this period, all experimental units were fed with control diet.

After 14 days feeding, fish were anesthetized by eugenol $(1 \%)$ and sacrificed by concussion, guts from two fish per experimental unit were removed and pooled, these samples were collected after $24 \mathrm{~h}$ without food. The pooled fish guts were homogenized and serially diluted by $1: 10$ in a $0.65 \% \mathrm{NaCl}$ sterile saline. Samples from each dilution were cultured in TCBS (thiosulfate citrate bile salts sucrose) agar, cetrimide agar, and Man, Rogosa, and Sharpe (MRS) (De Man et al., 1960) agar media and incubated for $48 \mathrm{~h}$ at $30^{\circ} \mathrm{C}$, for Vibrio spp., Pseudomonas spp., and lactic acid bacteria counts, respectively. These procedures were repeated two, four, and six days after the probiotic group was shifted to control diet (after 14 days).

On the second step, 252 Nile tilapia (O. niloticus) were used, average weight of $19.8 \pm 0.2 \mathrm{~g}$, distributed in 12 polyethylene boxes (800L), 21 fish per box, equipped with recirculation system and biological filter.

The experimental units were divided into four treatments (triplicate), fish fed with probiotic supplemented in: $100 \%, 50 \%, 25 \%$ and $0 \%$ (control) of feeds. The diet (GUABI ${ }^{\circledR} 36.0 \%$ crude protein, $10.0 \%$ moisture, $7.0 \%$ fat, $3.0 \%$ crude fiber, $1.2 \%$ ash, $6,000 \mathrm{mg}$ phosphorus, $15.0 \mathrm{~g}$ calcium, size 2-4mm, extruded, Manufacturer) was offered four times per day (8, 11,13 and 16 hour). And the probiotic was inoculated as previously described.
The dissolved oxygen and temperature (YSI PRO2030) were measured twice a day (9 and 15 hours), $\mathrm{pH}$ (Waterproof Tester, HANNA), total ammonia and nitrate according to the methodology described in APHA (Standard..., 2005) were weekly performed.

After nine weeks, the final weight $(\mathrm{g})$, final length (cm), weekly gain (g-week-1) survival, specific growth rate, yield, apparent feed efficiency, protein efficiency ratio and consumption $(\mathrm{kg})$ were evaluated.

All data were first subjected to Bartlett's analysis to verify the homogeneity of variance. For the fist step, microbiological data were $\log (\mathrm{x}+1)$ transformed, and all data were assessed by Student's - $t$ test. Microbial counts of the digestive tract from the probiotic group were analyzed by exponential regression. On the second, all data were subjected to one-way ANOVA, and significant differences among treatments were analyzed using the StudentNewman-Keuls (SNK) test. All of them were conducted at a $5 \%$ level of significance.

\section{RESULTS AND DISCUSSION}

Several studies confirm the probiotic effect of LAB for aquatic animals (Newaj-Fyzul et al., 2014; Ringø et al., 2014), however few evaluate the action time of these microorganisms in the host animals.

In this work, a higher BAL and lower Vibrio spp. concentration on days 0 and 2, and lower Pseudomonas spp. on day 0 in the intestinal tract of fingerlings fed probiotic (Figure 1). The reduction in Vibrio sp. and Pseudomonas sp. counts can be attributed to the ability of LABsupplemented diet to produce inhibitory substances (Balcázar et al., 2008; Jatobá et al., 2008; Vieira et al. 2008; Newaj-fyzul et al., 2014). This result corroborates that observed by Vieira et al. (2008) that offered L. plantarum for Pacific shrimp and observed that BALs maintained higher counts for four days and their probiotic effect (as immunostimulant) for up to six days after the last probiotic feeding. Although Nile tilapia have longer intestinal tract than Pacific shrimps, in this study LAB kept their counts higher only for four days after the last probiotic feeding, this difference may be related to the guest-host specificity. 

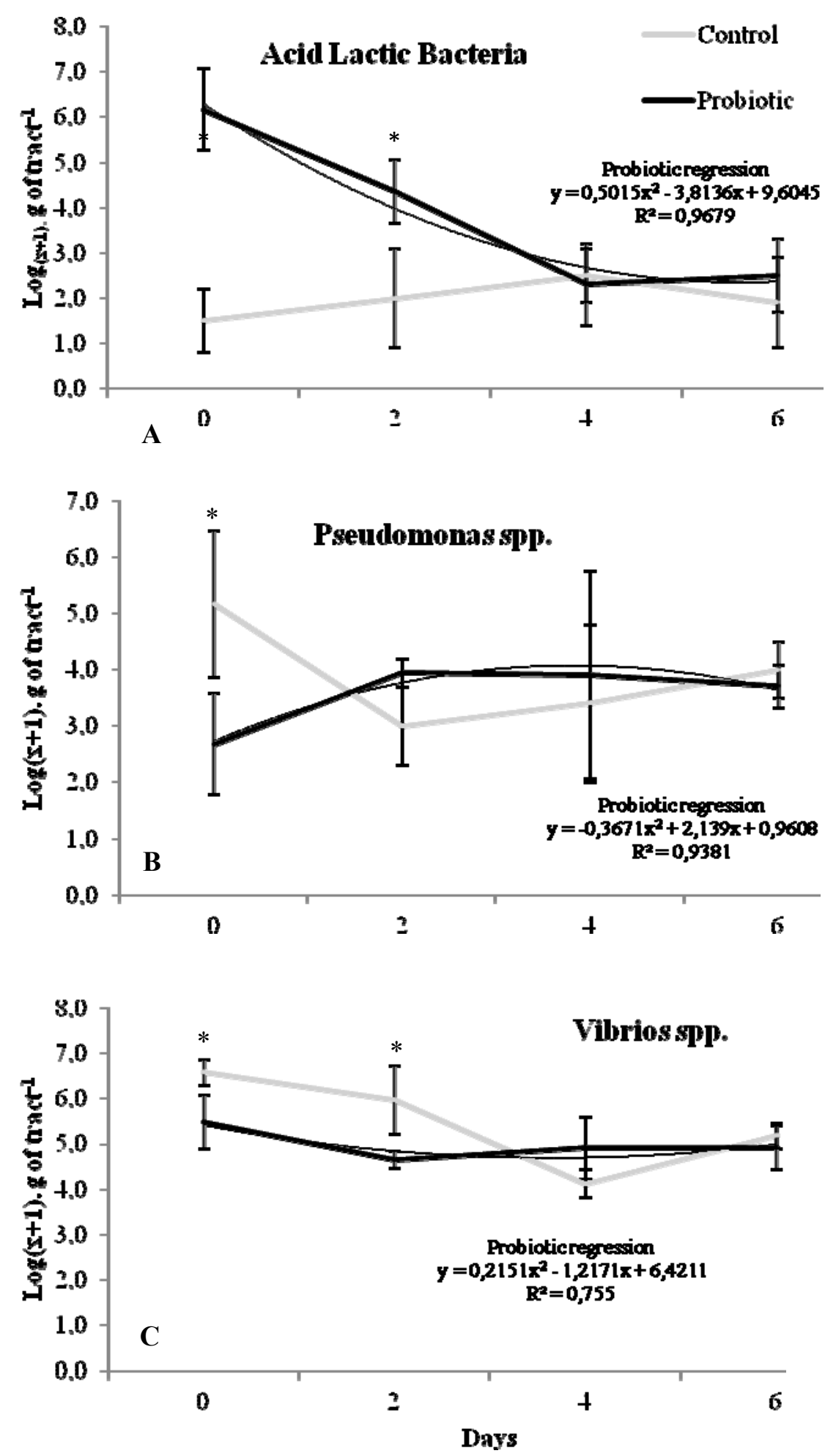

Figure 1. Microbiota changes for acid-lactic bacteria (A), Pseudomonas sp. (B) and Vibrios sp. (C) in the intestinal tract of Nile tilapia (Oreochomis niloticus), after 14 days of feeding with probiotic diet (Lactobacillus plantarum) or control. * Indicates statistical differences $(\mathrm{P}<0.05)$ between treatments in $\mathrm{t}$ test. 
On the growth performance, there were no significant differences observed among the treatments during experimental period, the temperature $\left(23.5\right.$ to $\left.24.3^{\circ} \mathrm{C}\right), \mathrm{pH}(7.5$ to 8.2$)$, dissolved oxygen $\left(6.9\right.$ to $\left.8.1 \mathrm{mg} \mathrm{L}^{-1}\right)$, total ammonia $\left(0.15\right.$ to $\left.0.27 \mathrm{mg} \mathrm{L}^{-1}\right)$ and nitrite $(0.01$ to $\left.0.07 \mathrm{mg} \mathrm{L}^{-1}\right)$ were suitable for the Nile tilapia (O. niloticus) culture (Shoko et al., 2016).

Probiotics are administered for Nile tilapia culture for long periods of time, varying from 15 days up to 8 months. Unfortunately, there is no evidence has proved how long the optimum period of time is, to obtain expected results, following the administration of probiotics into the culture systems (Van Hai, 2015). The same statement can be made regarding feed frequency required to obtain expected results (improvement in health and growth performance).

For the zootechnical indexes, fish fed with $100 \%$ and $50 \%$ of feeds supplemented with probiotic showed higher final weight, weekly weight gain, specific growth rate, yield, protein efficiency ratio and apparent feed efficiency than fish fed with $25 \%$ of probiotic supplemented and without supplementation. Final length and consumption did not vary between treatments (Table 1), as did survival that was $100 \%$ in all experimental units.

It is normal to find records about beneficial effects of probiotics on modulation and colonization in the fish microbiota, improving immune system (Jatobá et al., 2008; Jatobá e Mouriño, 2015; Standen et al, 2015; Van Hai, 2015), as well as growth promoter (Jatobá et al., 2011; Standen et al, 2016) for Nile tilapia fed with LAB as L. plantarum (Jatobá et al., 2008, 2011), probiotic multi-species (Standen et al, 2015), as well as, with commercial products (Standen et al, 2016), in all these trials probiotics were supplemented in all feeds for tilapia.

Table 1. Growth performance (average \pm standard deviation) of Nile tilapia fed, for nine weeks, with different frequencies of probiotic supplementation (Lactobacillus plantarum)

\begin{tabular}{|c|c|c|c|c|c|}
\hline \multirow{2}{*}{$\begin{array}{l}\text { Zootechnical } \\
\text { Indexes }\end{array}$} & \multicolumn{4}{|c|}{ Frequency (Probiotic supply / Total number of feeds on day) } & \multirow{2}{*}{$\begin{array}{c}\text { Significance } \\
(p)\end{array}$} \\
\hline & $100 \%(4 / 4)$ & $50 \%(2 / 4)$ & $25 \%(1 / 4)$ & Control $(0 / 4)$ & \\
\hline Final weight (g) & $69.26 \pm 1.41 \mathrm{~b}$ & $68.75 \pm 0.91 b$ & $66.07 \pm 1.42 \mathrm{a}$ & $66.02 \pm 1.02 \mathrm{a}$ & 0.015833 \\
\hline Final length $(\mathrm{cm})$ & $15.95 \pm 0.32$ & $16.30 \pm 0.27$ & $15.70 \pm 0.82$ & $15.45 \pm 0.35$ & 0.514604 \\
\hline WG (g.semana $\left.{ }^{1}\right)$ & $5.50 \pm 0.11 \mathrm{~b}$ & $5.44 \pm 0.07 \mathrm{~b}$ & $5.15 \pm 0.16 \mathrm{a}$ & $5.13 \pm 0.15 \mathrm{a}$ & 0.029425 \\
\hline SGR $\left(\% \cdot \operatorname{dia}^{-1}\right)$ & $0.78 \pm 0.02 b$ & $0.77 \pm 0.01 \mathrm{~b}$ & $0.75 \pm 0.01 \mathrm{a}$ & $0.75 \pm 0.01 \mathrm{a}$ & 0.010764 \\
\hline Yield $\left(\mathrm{kg} . \mathrm{m}^{-3}\right)$ & $0.74 \pm 0.01 \mathrm{~b}$ & $0.73 \pm 0.01 \mathrm{~b}$ & $0.74 \pm 0.02 \mathrm{a}$ & $0.74 \pm 0.01 \mathrm{a}$ & 0.040874 \\
\hline Consumption (kg) & $0.60 \pm 0.00$ & $0.60 \pm 0.00$ & $0.60 \pm 0.01$ & $0.60 \pm 0.02$ & 0.412739 \\
\hline $\mathrm{AFE}$ & $0.74 \pm 0.01 \mathrm{~b}$ & $0.73 \pm 0.01 b$ & $0.70 \pm 0.02 \mathrm{a}$ & $0.70 \pm 0.01 \mathrm{a}$ & 0.008651 \\
\hline PER & $2.04 \pm 0.05 \mathrm{~b}$ & $2.03 \pm 0.03 b$ & $1.94 \pm 0.04 \mathrm{a}$ & $1.93 \pm 0.05 \mathrm{a}$ & 0.004752 \\
\hline
\end{tabular}

*WG (weekly gain); SGR (specific growth rate); AFE (apparent food efficiency); PER (protein efficiency ratio); Different letters in the lines indicate significant differences between treatments in the SNK test.

Regardless of the chosen probiotic, there are production costs, Azevedo et al. (2015) observed best zootechnical performance and economic efficiency for Nile tilapia fed diet supplemented with prebiotics, probiotics, and symbiotics in the feed for Nile tilapia. Probiotic use in half $(50 \%)$ of feeds offered per day, can guarantee the same result as fish fed with probiotic in all $(100 \%)$ feeds. This would imply a $50 \%$ reduction in the cost of this technology, making it more attractive and viable for several producers.
L. plantarum acts, colonizing and modifying fish microbiota for 4 days after their last feed, and to obtain higher growth performance it must be supplemented in $50 \%$ of the feeds per day, for Nile tilapia (O. niloticus).

Keywords: Probiotics, Oreochomis niloticus, growth performance 


\section{RESUMO}

O objetivo desta pesquisa foi avaliar o tempo de ação do Lactobacillus plantarum no trato intestinal, assim como em qual frequência esse probiótico deve ser oferecido para tilápia-do-nilo (Oreochomis niloticus). Quarenta e oito tilápias foram alimentadas com ou sem probiótico, durante 14 dias. Após esse período, os peixes foram esviscerados, e amostras do trato intestinal foram semeadas em ágar TCBS, cetrimide e MRS. Esse procedimento foi repetido dois, quatro e seis dias após o $14^{\circ}$ dia. Depois disso, 252 tilápias foram divididas em quatro tratamentos, peixes alimentados com probiótico suplementado em 100\%, 50\%, 25\% e 0\% (controle) das alimentações. Após nove semanas, os índices zootécnicos foram avaliados. No dia zero, verificou-se maior concentração de bactérias ácido-lácticas e menor concentração de Vibrios spp. e de Pseudomonas spp. no trato intestinal dos alevinos alimentados com probiótico. Peixes alimentados com 100\% e 50\% das alimentações suplementadas com probiótico apresentaram melhores índices zootécnicos que os peixes alimentados com 25\% de suplementação e sem suplementação. $O \mathrm{~L}$. plantarum atuou por quatro dias após a última alimentação, e, para obter os melhores índices, essa cepa deve ser suplementada em 50\% das alimentações por dia para tilápia-do-nilo (O. niloticus).

Palavras-chave: probiótico, Oreochomis niloticus, performance de crescimento

\section{ACKNOWLEDGEMENTS}

The authors of this study acknowledge Conselho Nacional de Desenvolvimento Cientifico e Tecnológico (CNPq) for supporting (Processo 460362/2014-3) and offering scholarship (edital $n^{\circ} 23 / 2016$ IFC/CNPq) for the development of the project; GUABI for financing the diets used; and Klayton Moraes and Luiz Sérgio Moreira for technical support.

\section{REFERENCES}

AZEVEDO, R.V.D.; FOSSE FILHO, J.C.; CARDOSO, L.D. et al. Economic evaluation of prebiotics, probiotics and symbiotics in juvenile Nile tilapia. Rev. Cienc. Agron., v.46, p.72-79, 2015.

BALCÁZAR, J.L.; VENDRELL, D.; BLAS, I. et al. Characterization of probiotic properties of lactic acid bacteria isolated from intestinal microbiota of fish. Aquaculture, v.278, p.188$191,2008$.

DE MAN, J.C.; ROGOSA, M.; SHARPE, M.E. A medium for the cultivation of lactobacilli. $J$. Appl. Bacteriol., v.3, p.130-135, 1960.

GATESOUPE, F.J. The use of probiotics in aquaculture. Aquaculture, v.180, p.147-165, 1999.

JATOBÁ, A.; MOURIÑO, J.L.P. Lactobacillus plantarum effect on intestinal tract of Oreochromis niloticus fingerlings. Cienc. Anim. Bras., v.16, p.45-53, 2015.
JATOBÁ, A.; VIEIRA, F.N.; BUGLIONE, N.C. et al. Lactic-acid bacteria isolated from the intestinal tract of Nile tilapia utilized as probiotic. Pesqui Agropecu. Bras., v.43, p.12011207, 2008.

JATOBÁ, A.; VIEIRA, F.N.; BUGLIONE, N.C.C. et al. Diet supplemented with probiotic for Nile tilapia in polyculture system with marine shrimp. Fish Physiol. Biochem. v.37, p.725-732, 2011.

NEWAJ-FYZUL, A.; AL-HARBI, A.H.; AUSTIN, B. Review: developments in the use of probiotics for disease control in aquaculture. Aquaculture, v.431, p.1-11, 2014.

RINGØ, E.; OLSEN, R.E.; JENSEN, I.N. et al. Application of vaccines and dietary supplements in aquaculture: possibilities and challenges. Rev. Fish Biol. Fisher, v.24, p.1005-1032, 2014.

SHOKO, A.P.; LIMBU, S.M.; MROSSO, H.D.J. et al. Effect of stocking density on growth, production and economic benefits of mixed sex Nile tilapia (Oreochromis niloticus) and African sharptooth catfish (Clarias gariepinus) in polyculture and monoculture. Aquacul. Res., v.47, p.36-50, 2016.

Standard methods for the examination of water and wastewater. 21.ed. Washington: APHA, 2005. 541p. 
STANDEN, B.T.; PEGGS, D.L.; RAWLING, M.D. et al. Dietary administration of a commercial mixed-species probiotic improves growth performance and modulates the intestinal immunity of tilapia, Oreochromis niloticus. Fish Shellfish Immunol, v.49, p.427-435, 2016.

STANDEN, B.T.; RODILES, A.; PEGGS, D.L. et al. Modulation of the intestinal microbiota and morphology of tilapia, Oreochromis niloticus, following the application of a multi-species probiotic. Appl. Microbiol. Biotechnol., v.99, p.8403-8417, 2015.
VIEIRA, F.D.N.; BUGLIONE, N.C.C.; MOURIÑO, J.L.P. et al. Time-related action of Lactobacillus plantarum in the bacterial microbiota of shrimp digestive tract and its action as immunostimulant. Pesqui. Vet. Bras., v.43, p.763-769, 2008.

VAN HAI, N. Research findings from the use of probiotics in tilapia aquaculture: a review. Fish Shellfish Immunol., v.45, p.592-597, 2015. 